\title{
Dansk idrætshistorisk Forening - 10 år
}

\section{Af Else Trangboek}

Den 5. maj 1994 kunne Dansk Idrætshistorisk Forening Krop og kultur fejre sit 10 års jubilæum. Ti år er måske ikke så meget, men nok til at standse op og tænke efter hvad der er sket siden den dag i 1984, hvor foreningen blev stiftet. I det efterfølgende, som er min velkomsttale, i let omskrevet form, til jubilæumsseminaret: »Idrætshistorien på vej«, vil jeg tage udgangspunkt i undfangelsen og fødslen og de mange ord, som gode venner gav os med på vejen for afslutningsvis, at fremkomme med min vision om fremtiden.

\section{Undfangelsen}

I 1983 tog jeg, støttet af Idrættens Forskningsråd og inspireret af rigsarkivar og idrætshistoriker Jan Lindroth, Sverige, initiativ til afholdelse af et idrætshistorisk seminar. Der var på dette tidspunkt efterhånden mange, som på forskellig vis arbejdede med idrætshistorie, men de kendte ikke hinanden og var spredt ud over det ganske land. Til seminaret var inviteret alle der arbejdede i området, personer som havde vist området interesse, og personer, som jeg mente kunne hjælpe os et stykke på vej med kvalificeringen af idrætshistorien.

Landbohistorikeren Claus Bjørn indledte seminaret med et oplæg »Idrætshistorie i Danmark - synspunkter og sammenhæng «, hvor han startede med at citere Roar Skovmand fra Dansk skolehistorie 1967:
»Forskningen vedrørende dansk skolehistorie har været beskeden og utilstrækkelig, det gælder den ydre udvikling af lovgivningsrammer, administration, byggeri og lærerkræfter, som den indre udvikling og undervisningsindhold, fag, metode, karakter og målsætning, det gælder også sammenhængen med det øvrige samfunds udvikling og med tidsånden $\ll^{1}$

Claus Bjørn konstaterede, at det var dansk skolehistories situation i 1967, og fortsatte, at vi så måske blot kunne erstatte skolehistorie med idrætshistorie og konstatere, at det var situationen her og nu. Han fandt det betydningsfuldt, at den aktivitet der havde fundet sted og de personer, som havde skabt den siden slutningen af 70 'erne og begyndelsen af 80 'erne var tilstede ved seminaret. Derfor undlod han ikke at $\gg$ provokere« ved at sige

»....at hvor idrætshistorien for en snes år siden var utrolig fakta orienteret og rig på emperi, så kan man have lov at sige, at de sidste års idrætshistorie har udmærket sig ved vældige teoretiske armsving og markeret en vis fjernhed fra den idrætshistoriske virkelighed. $\ll^{2}$

Idrætshistorien var placeret, og seminariedeltagerne havde fået en vis form for karakter. Området var mangelfuld belyst, startskuddet havde lydt, men man skulle passe på de store armsving.

Seminaret sluttede med en diskussion, om hvorvidt vi i Danmark havde brug for et forum, «hvor den faglige og fagkritiske debat kunne finde sted «. Meningerne om en foreningsdannelse var delte. Nogle fandt, at 
det ville kunne cementere en blomstrende og mangfoldig udvikling af fèltet, men flertallet fandt dog, at en forening kunne »have gavnlige funktioner «. Men - skulle man lave en paraplyorganisation, der omfattede historie, sociologi, psykologi m.m. eller en enstrenget forening. Man enedes om, »at den forening, der skulle oprettes skulle have en humanistisk basis, og at det drejede sig om, at se mennesket og idrætten, i bred forstand, i et historisk perspektiv, hvortil mange fagområder naturligt kunne inddrages $«{ }^{3}$ Resultatet blev, at der blev nedsat en arbejdsgruppe, med det kommisorium at a) lave love og vedtægter til en forening, der udfra en bred historieopfattelse skal varetage den humanistiske idrætsforskning, b) komme med forslag til navn til foreningen og c) indkalde til stiftende generalforsamling. ${ }^{4}$

Arbejdsgruppen der blev nedsat bestod af Henning Eichberg, Per Jørgensen, Ove Korsgaard, Ole Rasmussen, Peter Arentzen og Else Trangbæk. Det tog ikke lang tid, at få skrevet udkast til vedtægter. ${ }^{5}$ At finde et dato til generalforsamling var også en enkel sag, men at give barnet navn var derimod vanskeligt.

Hvad skulle barnet hedde og skulle det være et selskab eller en forening. Skulle man vælge det eksklusive eller det mere folkelige - med appel til de mange. Valget faldt på det sidste, men grundet emnets karakter må foreningen vel nærmest betegnes som en blanding. Men tilbage var spørgsmålet om navnet. Skulle barnet kun signalere det »kedelige« historie, Dansk idrætshistorisk Forening eller skulle vi signalere nye »kropslige« tendenser. Skulle vi være en kropshistorisk eller idrætshistorisk forening. Det var vanskeligt at nå til enighed og kompromiset blev: Dansk idrætshistorisk Forening - Krop og kultur, hvilket ingen siden har fortrudt.

\section{Fodslen}

Den 5. maj 1984 blev foreningen således stiftet på Danmarks Højskole for Legemsøvelser. I den anledning havde vi bedt historiker og journalist Ole Lange om at give foreningen nogle gode råd med på vejen. ${ }^{6}$

Ole Lange tog i oplægget udgangspunkt i erfaringer i et andet forskningsfelt - arbejderbevægelsens historie.

Han gav 4 bud på idrætshistorisk forskning - og et par advarsler. Jeg vil kort nævne og kommenterere de punkter:

1. »Undgå alle de forsøg på monopolisering og usund rivalisering, som altid optræder, når noget nyt opstår.«

Ved foreningens start blev vi enige om at flest mulige interessenter, der arbejdede indenfor feltet på en eller anden vis skulle vore reprosenteret $i$ bestyrelse. Det bet $\phi d$, at generalforsamlingen dengang og siden har anbefalet, at der blev valgt personer ind med tilknytning til Institut for Idrat, Odense Universitet, Idratsforsk, Gerlev Idratshфjskole, Danmarks Højskole for Legemsфvelser, Kфbenhavn. Siden er også Center for Idratsforskning, Kobenhavns Universitet blevet reprosenteret. Alle er enige om, at det har varet en vigtigt model, fordi en så lille og landsdakkende forenin-

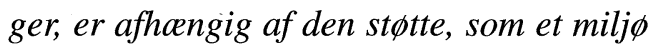
kan give. Dertil kommer, at modellen har sikret, at vi har fäet etableret et fagligt velfungerede netvark, hvor rivalisering har kunnet imфdegås. Problemet med denne struktur har derimod varet at sikre udskiftning og fornyelse i bestyrelsen. Det har vi på forskellig vis fors $\phi$ gt at afhjolpe ved at udvide bestyrelsen med suppleanter af varierende antal efter råd fra generalforsamlingen. 
2. »Hold vandene åbne mellem professionelle historikere og amatørhistorikerne. Lokalhistorien og de såkaldte amatører er-en del af faget. Den del er vigtigt, både fordi den er folkelig og tilfører ny viden $\ll$.

Her har vi måske ikke lykkedes så godtdet er en vanskelig sag. Der hvor foreningen primart har markeret sig udadtil har varet via vore årbøger og gennem de årlige seminarer. Begge steder har vi måske $i$ for høj grad satset på »Tordenskjolds soldater«, som bidragydere, hvilket måske har givet såvel seminarer som årbøger en form og et indhold, der ikke har haft appel til formålparagraffens brede gruppe. Vi har $i$ foreningen altid fors $\phi$ gt at sikre høj faglig kvalitet $i$ det vi har villet prasentere, og det finder vi naturligvis bedst hos de, hvis arbejde netop er at producere ny viden på området. Det betyder ikke, at vi ikke har forsøgt os med andre muligheder. Blandt andet har vi gennem de seneste år forsøgt, at inddrage studerende $i$ såvel foreningensom i formidlingen af deres studenterarbejder $i$ vore årbøger. Vi har på forskellig vis fors $\phi g t$, at inddrage ledere $i$ de frivillige foreninger i arbejdet, desvarre uden større held og amatorhistorikere indenfor idratten findes der kun få af $i$ Danmark -f.eks. $i$ modsatning til Sverige og Norge.

3. »Dyrk forbindelseslinierne til alle niveauer i uddannelsessystemet. Det er den vej, ny viden effektivt udbredes.« Vi har jfr. vores formålsparagraf bevidst arbejdet med formidling. Foreningen har, tør jeg godt påstå, varet af afgørende betydning for den idratshistoriske forskning. Ikke mindst har det varet af enorm betydning, at vi har haft en årbog, hvor ny viden har kunnet formidles. Det har varet af betydning for uddannelses- og skolesystemet, at nogle har formidlet materiale på nye teoriområder. For uden bøger ingen undervisning. De højere uddannelser, gymnasier og højskoler har trofast fulgt foreningens arbejde, og bakket os op med vedligeholdelse af medlemsskab. Der hvor vi ikke er nået ud i tilstrakkeligt omfang er til idratsledere/tranere. Der er ikke i disse miljøer tradition for at loese om idrattens kulturdet er måske for abstrakt. I idratten og foreningslivet iscenesatter man idratten $i$ stedet for at italesatte den.

4. »Undgå fagchauvinismen. Hold vandene åbne til andre samfundsvidenskaber især idrætsociologien, etnologi m.m. Skellene er kunstige, når det gælder udforskningen af et så jomfrueligt område som idræt/kropskultur. Målet er opnåelse af ny viden - uanset hvor den kommer fra«. Vi har fors $\phi$ gt at balancere mellem at vare historikere og kulturanalytikere $i$ bred forstand. Årbøgerne og debatterne på de årlige seminarer og generalforsamlinger kan dokumentere, at viften er bred. Dog har focus varet den humanistiske - og kulturelle tilgang, som allerede blev markeret som

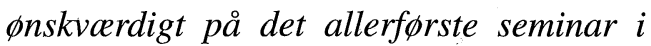
1983.

Ole Lange havde udover de gode råd også et par advarsler:

1. »De store teoretiske-akademiske diskussioner om afgrænsninger af genstandsområdet for forskningsaktiviteten kan blive golde. Den akademiske venstrefløjs erfaringer i 70érne er ikke opløftende. Meget endte i abstrakt skolastik, der både var lammende og ulæselig. Hold balancen mellem emperi og den faktaløse-teoretiseren.

og

2. Metodediskusionen er væsentlige. Men der findes ikke een korrekt eller rigtig metode. Der findes mange mulige. En 
given metode skal tilpasse det enkelte projekt alt efter problemet og kildematerialets karakter. Og så ændres den. Lad praksis vise metodens frugtbarhed.

Og Ole Lange sluttede med at det vigtigste for foreningen var:

»Der er opgaver nok til alle. Lad de 100 blomstre blomstre.«

Jeg har her - 10 år efter - stillet mig selv nogle spørgsmål. Hvad var der sket, hvis vi ikke havde fået en forening? Det kan naturligvis kun blive gisninger, idet jeg naturligvis ikke tilskriver foreningen hele æren for den idrætshistoriske udvikling. Men - uden at rødme tør jeg godt tilskrive den en stor del heraf. Jeg forsøger med et par spørgsmål:

* Havde vi så i tillidsfuldt samarbejde kunnet udvikle et fagfelt, som vi faktisk har gjort?

* Hvorledes havde uddannelsessystemet set ud uden materiale og aktive netværk?

* Hvordan var der blevet taget vare på den kulturelle arv?

Jeg tror, at det er meget vigtigt i en tid, som vores, med så store forandringer, at vi øger den historiske og kulturelle bevidsthed. Jeg tror også, at kulturhistorien er en god ballast, når der skal træffes politiske beslutnin- ger. Visioner uden forbindelse til rodnettet kan let risikere at forblive visioner.

Hvis jeg kort skulle skitsere mine ønsker for fremtiden, kan det gøres kort i følgende:

* at vi kan fastholde fagligheden

* at vi kan udvide vore netværk - sikre dialogen mellem fagfæller

* at vi kan etablere en meget bedre dialog med idrætten, medlemmer, ledere og andre d.v.s. at sikre dialogen mellem fagfolk og brugere

* at politikere og idrættens beslutningstagere vil samarbejde med og lade sig inspirere af personer med kulturhistorisk tilgang til idrætten

Foreningen har gennem de 10 første år været afhængig af især to bidragydere: Idrættens Forskningsråd og Kulturministeriet. Uden denne støtte havde der ikke været en forening $i$ dag.

Jeg ser her et nybrud i forbindelse med dette jubilæum, idet vi for det kommende år har modtaget tilsagn fra Idrættens Fællesråd, at de, i hvert tilfælde, det kommende år vil yde foreningen støtte. Jeg ser herigennem en mulighed for at nogle af de forhold, som har været vanskelige for foreningen de første 10 år, nemlig dialogen med idrættens aktører, kan få øget betydning i arbejdet fremover.

\section{Anvendt Litteratur}

Rapport fra Idrætshistorisk Seminar den 7. - 8. oktober 1983, DHL 1983

Idrætshistorisk Årbog 1985, nr. 1, Dansk Idrætshistorisk Forening Krop og Kultur 1985 


\section{Noter}

1. Rapport fra Idrætshistorisk Seminar, side 9

2. ibid side 9

3. ibid side 88

4. ibid side 88
5. se de første vedtægter i: Idrætshistorisk Årbog 1985, side 208-209

6. Lange, Ole, Den glemte historie. I: Idrætshistorisk Årbog 1985, nr. 1, side 9-13 


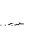

